DOI: 10.28995/2227-6165-2019-1-108-114

\title{
О.А. Богданова
}

доктор филологических наук, ведущий научный сотрудник Института мировой литературы имени А.М. Горъкого РАН olgabogda@yandex.ru

\section{АРХИТЕКТУРА В ЗЕРКАЛЕ ЛИТЕРАТУРЫ: «УСАДЕБНЫЙ ТЕКСТ» В ПРОИЗВЕДЕНИЯХ РУССКИХ ПИСАТЕЛЕЙ 1920-X гг. ${ }^{*}$}

На материале произведений русских писателей 19101920-х гг. показано, что каждая из изображенных ими усадеб или деталей интерьера имеет черты архитектурнодекоративных стилей барокко, классицизма, ампира, модерна. Однако точки зрения рассказчика или персонажа, сквозь призму которых мы различаем эти стили, кладут на них печать личного восприятия, обусловленного авторским идейно-эстетическим заданием. Более того, они могут создавать из разрозненных барочных и ампирных деталей одностильные ансамбли, единственно путем их духовноэмоционального преображения, как это происходит в рассказе И.А. Бунина «Несрочная весна» (1923).

Ключевъе слова: усадьба-музей, 1920-е гг., архитектура, литература, стиль, рассказчик, персонаж, точка зрения
Based on the works of Russian writers of 1910-1920s, it is shown that each of the estates or interior details depicted by them has features of architectural and decorative styles of Baroque, Classicism, Empire, Modern. However, the point of view of the narrator or character, through the prism of which we distinguish these styles, put on them the seal of personal perception, due to the author's ideological and aesthetic task. Moreover, they can create single-style ensembles from single Baroque and Empire details only by their spiritual and emotional transformation, as it happens in the story of I. Bunin “Non-urgent spring” (1923).

Keywords: estate-museum, 1920s, architecture, literature, style, storyteller, character, point of view

В ходе революции 1917-1918 гг. происходил массовый разгром помещичьих усадеб, расхищение и уничтожение хранившихся там культурных ценностей. В то же время одним из противоречивых начинаний новой власти стала деятельность созданного в 1918 г. Музейного отдела Наркомпроса по выявлению, взятию на учёт и сохранению наиболее известных дворянских усадеб и их коллекций. К осени 1918 г. было принято более десятка декретов и распоряжений советского правительства, которые касались вопросов сохранения культурного наследия, в том числе и дворянских усадеб [Рязанцев, 2009, с. 3-5]. Завершил процесс декрет Совета народных комиссаров РСФСР от 5 октября 1918 г. «О регистрации, приеме на учет и охранении памятников искусства и старины, находящихся во владении частных лиц, обществ и учреждений». Так на территории РСФСР стали появляться усадьбы-музеи: литературно-мемориальные и музеи усадебного быта.

Одним из первых стал музей, организованный в 1919 г. в бывшем имении дворян Барышниковых Алексино Дорогобужского уезда Смоленской губернии. По ходатайству его основателя Н.И. Савина, в начале марта 1921 г. заведующим этим учреждением был назначен писатель-этнограф М.М. Пришвин, командированный Наркомпросом в Дорогобужский уезд для изучения памятников искусства, старины и природы. Это была богатейшая усадьба, жемчужина архитектуры, созданная на рубеже XVIII-XIX вв. архитекторами Доменико Жилярди и М.Ф. Казаковым. Ее владельцы были щедрыми меценатами, много сделавшими для развития образования, науки и искусства в

(C) Богданова О.А., 2019

* Работа выполнена в ИМЛИ РАН за счет средств гранта РНФ № 18-18-00129 «Русская усадьба в литературе и культуре: отечественный и зарубежный взгляд». 


\section{O.A. Bogdanova Architecture in the mirror of literature:}

the "estate text" in the works of Russian writers of the 1920s

Смоленском крае. Именно в Алексине происходит действие повести Пришвина «Мирская чаша. 19-й год XX века» (1922), о которой речь пойдет ниже. Близлежащая Овиновщина (одно из роскошных имений князей Урусовых), построенная во второй половине XVIII в., возможно, стала прототипом усадьбы, изображенной в повести Николая Огнёва [М.Г. Розанова] «Дневник Кости Рябцева» (1926-1927).

Известное литературное гнездо, обширная подмосковная усадьба Вяземских - Шереметевых Остафьево, принимавшая под свой кров Н.М. Карамзина, А.С. Пушкина и В.А. Жуковского, была национализирована еще в 1917 г. Хранителем теперь уже «народного достояния» назначили бывшего владельца Остафьева графа П.С. Шереметева, историка и талантливого художника. Возможно, именно его изобразил И.А. Бунин в одном из эпизодов рассказа «Несрочная весна» (1923) в лице «бывшего профессора», «бывшего богатого человека», получившего надел в деревне при своем бывшем имении. Посещение Остафьева осенью 1918 г. стало одним из последних впечатлений писателя-эмигранта о России. Основное же действие в этом рассказе Бунина происходит в усадьбе графов Орловых-Давыдовых Отрада-Семеновское в 70 км от Москвы (см.: [Бабореко, 1995]). После 1917 г. в главном доме этой усадьбы был ненадолго устроен музей дворцового быта, в 1918-1920 гг. здесь располагался детский дом имени Карла Маркса, затем техникум и школа крестьянской молодежи.

Также одним из первых было музеефицировано богатейшее имение князей Юсуповых великолепное подмосковное Архангельское. В 1917-1918 гг., во избежание разграбления оставленного хозяевами имения, «<...> бывшие служащие <...> по собственной инициативе взяли усадьбу под опеку, добились предоставления охранной грамоты от Военно-Революционного Комитета г. Москвы на дворец и его коллекции» [Госуд. музей-усадьба «Архангельское»]. В 1919 г. музей в усадьбе был открыт для посетителей. Именно Архангельское стало прототипом булгаковской «Ханской ставки» в рассказе «Ханский огонь» (см.: [Енишерлов, 2012, с. 143-144]).

Музеефикация усадеб в грозовые революционные годы чаще всего воспринималась как явление положительное и в сложившихся обстоятельствах желательное: во-первых, она обеспечивала сохранность памятника культуры, его защиту от разграбления и уничтожения; вовторых, достигалась просветительная цель - многочисленные посетители получали знания и представление о жизни и творчестве выдающихся деятелей прошлого, люди из народа имели возможность повысить свой культурный уровень; в-третьих, музеи становились центрами изучения истории русской литературы и культуры, их экспозиции и архивы привлекали ученых, исследователей.

Поэтому неудивительно, что в «усадебной» тематике русской литературы 1920-х гг. возник новый аспект - изображение усадеб-музеев и осмысление их роли в культурной истории страны. Необходимо отметить, что в настоящей статье не ставится цель сравнить архитектурные особенности реальных усадеб-прототипов с их изображением в литературных произведениях, отсутствует намерение оценить фактическую достоверность описаний или показать степень разрушения русской «усадебной культуры» в послереволюционные годы. Мы исходим именно из художественного образа усадьбы в конкретном произведении, который может быть существенно удален от своего прототипа. Поэтому здесь практически нет обращений к архитектурному или искусствоведческому анализу Архангельского, Остафьева, Алексина, Отрады-Семеновского и т.д. как исторически сложившихся разностильных ансамблей, по которым имеется обширная специальная литература, но говорится о тех более или менее ясно различимых архитектурностилевых и декоративных деталях, которые присутствуют в литературных текстах. Их воспроизведение вербальными средствами, а также особенности восприятия авторами и персонажами во многом определяют как «условность», так и «системность» созданного художественного мира: во-первых, здесь господствуют «вымысел» или «домысел», хотя «строительным материалом» служит первичная реальность (см.: [Хализев, 200о, с. 157-159; Чернец, Хализев, Эсалнек и др., 2004, с. 178-179; Чернец, Семенов, Скиба, 2013, с. 113-114]); во-вторых, 
О.А. Богданова Архитектура в зеркале литературы: «усадебный текст» в произведениях русских писателей 1920-х г2.

композиция сюжета и смена точек зрения персонажей выстраиваются в контексте таких архитектурных, декоративных и живописных деталей, которые передают общий культурный стиль той или иной эпохи русской истории с присущим ему мировоззрением. Так, например, елизаветинское барокко стремилось прославить молодую Российскую империю в формах, указывающих на могучую витальность ее разнообразной природы и величие государственных деятелей с их грандиозными свершениями. Рациональная иерархичность александровского классицизма и ампира была призвана передать чаемую гармонию устройства человеческой жизни как в масштабе семьи, так и страны. Черты стиля модерн в интерьере транслируют представление об опасном расширении диапазона человеческой чувствительности и о власти во внутреннем мире личности темного бессознательного начала, ведущего к саморазрушению. Игра возникающими смыслами при сопоставлении разностильных деталей служит передаче авторского идейноэстетического задания.

Итак, в поле нашего зрения оказались: повести Николая Огнёва [М.Г. Розанова] «Дневник Кости Рябцева» (1926-1927) и М.М. Пришвина «Мирская чаша. 19-й год XX века» (1922), рассказы И.А. Бунина «Несрочная весна» (1923) и М.А. Булгакова «Ханский огонь» (1923). Наблюдение Л.М. Яновской о характере изображения Архангельского в последнем рассказе можно распространить на все перечисленные произведения: «Булгаков не случайно дал другое название описанному им дворцу. Образные впечатления Архангельского сдвинуты и свободно перекомпонованы им <...>. Посетители в рассказе по белой лестнице с малиновым ковром подымаются в парадные комнаты второго этажа, где-то внизу оставляя библиотеку, тогда как во дворце Архангельского парадные залы находятся на первом этаже, а библиотека <...> размещалась в более скромных комнатах второго. <...> Перекомпонованные, но живые, второю жизнью живущие приметы Архангельского волнуют <...> [Яновская, 1974, с. 125].

Каждая из изображенных усадеб или деталей интерьера наделена авторами теми или иными чертами, которые можно отнести к архитектурным стилям барокко, классицизма, ампира, модерна. Однако точка зрения рассказчика или персонажа, сквозь призму которой мы различаем эти стили, придает им активный культурно-ценностный характер, так или иначе воспринимаемый человеком другой эпохи. Рассказчики в рассматриваемых произведениях очень разные: иногда они приближены к авторам (как в «Мирской чаше» и «Несрочной весне»); бывает, что точка зрения отдана персонажам: то советскому подростку и старорежимному полуграмотному сторожу (как в «Дневнике Кости Рябцева»), то наивному честному старику - бывшему княжескому камердинеру - или отчаявшемуся бывшему владельцу (как в «Ханском огне»).

В повести Огнёва посещение «показательного музея» в имении князей Урусовых для знакомства с тем, как «жили раньше баре, помещики и буржуи» [Огнёв, 2006, с. 209], дается с точки зрения типичного советского школьника, воспринимающего прежнюю жизнь как окончательно побежденное эксплуататорское прошлое. Интерьер и убранство читатель видит сквозь призму неграмотной речи сторожа, выдающего себя за экскурсовода: «Здесь <...> помещик, его превосходительство господин Урусов, обедали, а здесь его превосходительство чай пили. А здесь его превосходительство отдыхали. <...> [Огнёв, 2006, с. 204]. Затем, продолжает Костя, «приходим в громадный зал, с хорами; посредине висит большущая люстра в чехле; а окна чуть не с целую футбольную площадку» [Огнёв, 2006, с. 206]. Как видим, обоих созерцателей усадебных интерьеров роднит утилитарный, а не эстетический характер восприятия. В описании подростка угадываются архитектурные детали классицизма; этот стиль ассоциируется с блестящим периодом имперского загородного строительства - концом XVIII в.

Сторож - старик, служивший еще князю Урусову, то есть усадебный домочадец. Неудивительно, что в залах дворца он чувствует себя как дома: ест, пьет, отдыхает, даже использует самогонный аппарат в комнатке под лестницей. Группу приехавших детей из-за продолжительного дождя он оставляет ночевать в помещении музея, постелив им сена, взятого с усадебно-совхозного скотного двора, и напоив их молоком совхозных коров. К тому же он хранитель местных преданий: 


\section{O.A. Bogdanova Architecture in the mirror of literature:}

the "estate text" in the works of Russian writers of the 1920s

в «громадном зале» «его превосходительство господин Урусов зарезались...» из-за встречи с привидением - некоей «белой мадамой» [Огнёв, 2006, с. 206]. Однако страх сторожа перед привидением, за которым, возможно, стоит трагическая история возвышенной любви, для школьников лишь повод к опасным шуткам. Усадебная легенда оборачивается грубым фарсом, использующим притупленное восприятие полупьяного старожила. Сниженный образ слугидомочадца способствует развенчанию самой «усадебной культуры», лишая ее ореола величия, изящества, гармонии.

Совсем иная авторская позиция - в «Мирской чаше» Пришвина. В «ампирном дворце» бывшего имения разместились детская колония, школа, разные советские конторы и учреждения, и только пять комнат во втором этаже не тронуты - в них организован «музей усадебного быта». В разоренном парке от прежних времен остались два павлина, которых охраняет столетняя Павлиниха, категорически не приемлющая новых порядков.

Музей - дело жизни автобиографического героя Алпатова, он создается как необходимый для преодоления народного «обезьяньего» рабства очаг культуры, образец прекрасного, оплот высших - христианских - ценностей бытия, надежда на пробуждение личностного самосознания в народной толще («воскресение <...> из числа» [Пришвин, 2006, т. 1, с. 604]) в противовес сугубо материальным нуждам, в которых погрязли деревенские жители. Интересно, что построенный в стиле позднего классицизма дворец Алпатов обустраивает на свой манер, на собственный вкус, в соответствии со своими просветительными целями. В «большой зале» в стиле александровского ампира «были развешаны портреты с Петровской эпохи до нашего времени», к каждому «был подобран текст из поэтов усадебного быта» [Пришвин, 2006, т. 1, с. 596]. В одностильной «колонной гостиной» разместился «драгоценный бювар с колонками слоновой кости, всякие старинные шифоньерки, шкафчик с французскими писателями XVIII века» [Пришвин, 2006, т. 1, с. 596], на стенах - миниатюры, акварели, пастели, офорты. Следующая комната, «по недостатку мебели ампирной», была посвящена 1860-м годам - «эпохе великих реформ» [Пришвин, 2006, т. 1, с. 596]. «Сюда в память Тургенева были собраны портреты интересных женщин <...> [Пришвин, 2006, т. 1, с. 596]. «В охотничьем кабинете было старинное оружие, чучела местных зверей: лося, медведя, рыси, диких коз <...>, вся эта комната была зеленая: портьеры, ковры, обои <..>» [Пришвин, 2006, т. 1, с. 597]. Именно здесь устроился жить сам музейный заведующий, «рассчитывая, что хороший камин спасет его от холода» [Пришвин, 2006, т. 1, с. 597]. А в пятой, последней комнате, в соответствии с архаическими веяниями эпохи модерна, «на гигантском пне» был поставлен «слепок пантикапейской вазы с изображением скифа» как символ крестьянской России - «безликой таинственной Скифии со спящей красавицей», ожидающей, в лице Алпатова и других работников культуры, «своего Ивана-царевича» [Пришвин, 2006, т. 1, с. 598]. Простонародное же восприятие музея однозначно: «<...> тут, на блестящем паркетном полу среди зеркал, колонн и картин, женщина моховых болот уверенно скажет: Рай!» [Пришвин, 2006, т. 1, с. 598].

В рассказе Бунина отношение к русской помещичьей усадьбе еще более восхищенное и почтительное, однако авторский тон пессимистичен. Приезжающий в бывшее княжеское поместье автобиографический герой-рассказчик встречает, благодаря устроенному там новой властью музею, неразграбленные, нетронутые чужой рукой покои, библиотеку, кабинет, картинную галерею. Необходимо заметить, что главный дом усадьбы В.Г. Орлова Отрада-Семеновское, послуживший прототипом для писателя, был построен в конце 1770-х гг. в стиле, промежуточном между барокко и классицизмом, что было характерно для той эпохи. Однако в бунинских описаниях чувствуются скорее барочные пропорции и формы: в верхних покоях дворца «[п]отолки блистали золоченой вязью, гербами, латинскими изречениями. <..> В лаковых полах отсвечивала драгоценная мебель. В одном покое высилась кровать <...> под балдахином из красного атласа <...> [Бунин, 2006, т. 4, с. 213]; в нижних залах располагалось книгохранилище со сводчатыми потолками и окнами «с железными толстыми решетками» [Бунин, 2006, т. 4, с. 213], огромный 
О.А. Богданова Архитектура в зеркале литературы:

«усадебный текст» в произведениях русских писателей 1920-х г2.

телескоп и гигантский планетарий. Сохранились редкие книги и гравюры, часы с колоколами, средневековый орга́н, многочисленные статуи и портреты - все изящное и драгоценное убранство «несказанно прекрасного» дворца. Также, по-видимому, в рассказе не случайно упомянуты неоднократные посещения усадьбы императрицей Екатериной II, обычно проживавшей в унаследованных ею пышных барочных резиденциях: Зимнем дворце, Царском Селе, Петергофе и др., - несмотря на личные симпатии к классицизму, ее царствование ассоциировалось скорее с блестящей грандиозностью стиля барокко. Существовало и так называемое «екатерининское барокко», или барочетто, черты которого ясно различимы именно в усадьбе Отрада-Семеновское (см.: [Екатерининское барокко]).

В английском усадебном парке герой-рассказчик видит каменный мост, ворота со львами, старинные аллеи, шедевр архитектуры - «круглую, палевого цвета» церковь с «золотой маковкой» над «желтоватыми мраморными колоннами» [Бунин, 2006, т. 4, с. 214], прекрасные пруды, на озере - «остров с павильоном» [Бунин, 2006, т. 4, с. 212]. «Красавцы и красавицы» с фамильных портретов, чьи останки покоятся в мозаичном склепе под пустой светлой церковью, отдали годы своей жизни «во славу и честь Державы Российская» [Бунин, 2006, т. 4, с. 213], которой, по мысли рассказчика, больше нет и никогда не будет. Прототипом для Бунина стала, по всей видимости, церковь Успения Пресвятой Богородицы с подземным склепом, где покоились в медных гробах пятеро братьев Орловых, в том числе знаменитые екатерининские сподвижники Григорий и Алексей. Она построена в 1835 г. в стиле ампир архитектором Доменико Жилярди. Однако в рассказе «буйное и дремотное волнение сосен» [Бунин, 2006, т. 4, с. 215] в узких окнах усыпальницы создает очевидный барочный декор: «<...> ветер ворочает косматые главы сосен, величаво и дико раскинутые из обрыва в уровень с окнами, и слышно пение, гул ветра» [Бунин, 2006, т. 4, с. 214]. Таким образом, церковь и дворец в произведении становятся одностильным ансамблем, олицетворяющим «усадебную культуру» на пике ее развития - в екатерининскую эпоху. Средоточие всего лучшего в России, она представляется рассказчику абсолютным прошлым, потерянным, недостижимым идеалом. Его взгляд вносит в увиденные интерьеры именно такой смысл.

Действие булгаковского «Ханского огня» также происходит в великолепном имении, сохранившем как барочные (парадная лестница), так и классицистические (бальный зал) и ампирные (парадный кабинет) интерьеры, заполненные бесценными произведениями искусства, а также помещения начала XX в. в стиле модерн («розовая» спальня княжеской четы с «зеркало[м] в раме серебряных листьев, альбом[ом] на столике в костяном переплете», «гранены[ми] флакон[ами], карточк[ами] в светлых рамах, брошенн[ой] подушк[ой]<...» [Булгаков, 2004, т. 1, c. 487]; рабочий кабинет Антона Иоанновича). Главный дом со всем убранством уцелел благодаря организации в нем музея «Ханская ставка»: экскурсанты могут увидеть интерьеры разных эпох - бальный зал, гостиные, картинную галерею, кабинеты, спальню, курительные, боскетные, игральные, бильярдные комнаты.

В центре рассказа два героя: сам вернувшийся инкогнито из-за границы последний князь Тугай-Бег-Ордынский, бывший владелец национализированного имения, и музейный сторож Иона Васильевич, его бывший слуга-домочадец, для которого княжеская семья и быт - как свои собственные. Во время экскурсии он испытывает душевную боль из-за вторжения чужих людей в «живой», как будто жилой дом Тугай-Бегов.

Композиционно рассказ делится на три части: экскурсия, разговор Тугай-Бега с Ионой, ТугайБег один в своем рабочем кабинете. Экскурсия проводит читателя по всему дворцу как наглядной истории русской культуры в многоголосом восприятии посетителей и самого Ионы. Разговор проходит в дверях изящного бального зала в стиле классицизм и затем в ампирном парадном кабинете эпохи Александра I. Эти интерьеры созданы в десятилетия расцвета и наивысшего подъема «усадебной культуры»; Иона и князь встречаются в них как члены одной семьи. В конце рассказа действие перемещается в личный рабочий кабинет Тугай-Бега, в котором более функциональная обстановка начала XX в., свойственная эпохе модерна: керосиновая лампа с 


\section{O.A. Bogdanova Architecture in the mirror of literature:}

the "estate text" in the works of Russian writers of the 1920s

зеленым стеклом, глухие черные шторы, сидячая конторка, памятные фотографии на стенах. Теперь князь один, повествование заполняется его больным, озлобленным, субъективноизолированным восприятием. Именно отсюда начинается процесс разрушения, а затем поджога дворца. Как известно, Серебряный век - время заката традиционной дворянской «усадебной культуры» в России.

Симптоматично, что в рассказе Булгакова музей-усадьба упразднен не советской властью (как в «Мирской чаше» Пришвина), но самим бывшим владельцем: «Не вернется ничего. Все кончено. Лгать не к чему. Ну так унесем же с собой все это <...> [Булгаков, 2004, т. 1, с. 496]. Князь собственными руками уничтожает прекрасную усадьбу, аккумулировавшую в себе огромные культурные сокровища и славную историческую память о знатном пятисотлетнем роде, героически послужившем России. Это своего рода нигилизм, самоубийство, обусловленное его сословным эгоизмом, недостатком социальной солидарности с демократическими слоями нации. Вспомним его ненависть к экскурсантам, отторжение мысли о библиотеке для крестьян в своем дворце, пренебрежение безопасностью Ионы. Ведь ему, как музейному сторожу, не поздоровится из-за устроенного князем поджога.

Итак, именно точка зрения рассказчиков и других персонажей создает в рассмотренных произведениях модус восприятия каждого архитектурно-декоративного стиля как художественной детали, реализует те или иные коммуникативные стратегии, придает усадебным строениям и интерьерам определенные ценностные смыслы.

\section{источники}

1. Бабореко А.К. Комментарий / А.К. Бабореко // Бунин И.А. Собр. соч.: В 8 т. Т. 4. - Москва: Московский рабочий, 1995. - C. 516-518.

2. Булгаков М.А. Ханский огонь / М.А. Булгаков // Булгаков М.А. Собр. соч.: В 8 т. Т. 1. - Москва: ЗАО Центрполиграф, 2004. - С. 481-496.

3. Бунин И.А. Несрочная весна / И.А. Бунин // Бунин И.А. Полн. собр. соч.: В 13 т. Т. 4. - Москва: Воскресенье, 2006. - C. 208-218.

4. Государственный музей-усадьба «Архангельское». Официальный сайт.

http://arhangelskoe.su/the_museum/history_museum/

5. Огнёв Николай. Дневник Кости Рябцева / Николай Огнёв. - Москва: Астрель; АСТ; Транзиткнига, 2006.

6. Пришвин М.M. Мирская чаша. 19-й год XX века / М.М. Пришвин // Пришвин М.M. Собр. соч.: В 3 т. Т. 1. - Москва:

Терра - Книжный клуб, 2006. - С. 583-667.

\section{ЛИТЕРАТУРА}

1. Екатерининское барокко. http://spbiir.ru/nauka/mir-iskusstva/arhitekturnye-stili/barokko/ekaterininskoe-barokko/

2. Енишерлов В. В Архангельском гаснет факел жизни / В. Енишерлов // Наше наследие. № 101. 2012. - С. 138-146.

3. Рязанцев Н.П. Материалы музейного отдела Наркомпроса об охране дворянских усадеб (1918 - начало 1920-х гг.) / Н.П. Рязанцев // Русская усадьба XVIII - начала XXI вв. Проблемы изучения, реставрации и музеефикации: Материалы научной конференции. Ярославль, 2-3 июля 2009 г. / Сост. Е.В. Яновская. - Ярославль, 2009. - С. 3-9.

4. Хализев В.Е. Теория литературы. Изд. 2-е. / В.Е. Хализев. - Москва: Высшая школа, 2000.

5. Чернец Л.В., Хализев В.Е. Эсалнек А.Я. и др. Введение в литературоведение: Учеб. пособие / Л.В. Чернец, В.Е. Хализев, А.Я. Эсалнек. - Москва: Высшая школа, 2004.

6. Чернец Л.В., Семенов В.Б., Скиба В.А. Школьный словарь литературоведческих терминов: мир художественного произведения. Стилистика. Стиховедение. Литературный процесс. 4-е изд., доп. / Л.В. Чернец, В.Б. Семенов, В.А. Скиба. - Москва: Просвещение, 2013.

7.Яновская Л.М. О рассказе Михаила Булгакова «Ханский огонь» / Л.М.Яновская // Наш современник, 1974, 2. - С. 124-126. 
О.А. Богданова Архитектура в зеркале литературы: «усадебный текст» в произведениях русских писателей 1920-х г2.

\section{SOURCES}

1. Baboreko A.K. Kommentariy [Comment]. In: Bunin I.A. Sobr. soch.: V 8 t. T. 4 [Works: In 8 vols. 4]. Moscow, Moskovskiy rabochiy Publ., 1995, pp. 516-518.

2. Bulgakov M.A. Khanskiy ogon [Khan's fire]. In: Bulgakov M.A. Sobr. soch.: V 8 t. T. 1 [Works: In 8 vols. 1]. Moscow, ZAO Tsentrpoligraf Publ., 2004, pp. 481-496.

3. Bunin I.A. Nesrochnaya vesna [Non-urgent spring]. In: Bunin I.A. Poln. sobr. soch.: V 13 t. T. 4 [Complete works: In 13 vols. 4]. Moscow, Voskresenye Publ., 2006, pp. 208-218.

4. Gosudarstvennyy muzey-usadba «Arkhangelskoye». Ofitsialnyy sayt [State Museum-estate “Arkhangelskoje”. Official site]. http://arhangelskoe.su/the_museum/history_museum /

5. Ognev Nikolay. Dnevnik Kosti Ryabtseva [Diary of Kostya Ryabtsev]. Moscow, Astrel; AST; Tranzitkniga Publ., 2006.

6. Prishvin M.M. Mirskaya chasha. 19-y god XX veka [Secular Cup. The 19th year of XX century]. In: Prishvin M.M. Sobr. soch.: V 3 t. T. 1 [Works: In 3 vols. 1]. Moscow, Terra - Knizhnyy klub Publ., 2006, pp. 583-667.

\section{REFERENCES}

1. Ekaterininskoye barokko [Catherine's Baroque]. http://spbiir.ru/nauka/mir-iskusstva/arhitekturnyestili/barokko/ekaterininskoe-barokko/

2. Enisherlov V. V Arkhangelskom gasnet fakel zhizni [In Arkhangelskoje the torch of life goes out]. In: Nashe naslediye [Our heritage], no 101, 2012, pp. 138-146.

3. Ryazantsev N.P. Materialy muzeynogo otdela Narkomprosa ob okhrane dvoryanskikh usadeb (1918 - nachalo 1920-kh gg.) [Materials of the Museum Department of the people's Commissariat for the protection of noble estates (1918-early 1920s)]. In: Russkaya usadba XVIII - nachala XXI vv. Problemy izucheniya. restavratsii i muzeyefikatsii: Materialy nauchnoy konferentsii. Yaroslavl. 2-3 iyulya $2009 \mathrm{~g}$. [Russian estate of XVIII - early XXI centuries. Problems of study, restoration and museumification: Proceedings of the scientific conference. Yaroslavl, 2-3 July 2009], ed. by E.V. Yanovskaya. Yaroslavl, 2009, pp. 3-9.

4. Khalizev V.E. Teoriya literatury [Theory of literature], ed. 2. Moscow, Vysshaya shkola Publ., 2000.

5. Chernets L.V.. Khalizev V.E. Esalnek A.Ya. etc. Vvedeniye $v$ literaturovedeniye: Ucheb. posobiye [Introduction to literary studies: textbook]. Moscow, Vysshaya shkola Publ., 2004.

6. Chernets L.V.. Semenov V.B.. Skiba V.A. Shkolnyy slovar literaturovedcheskikh terminov: mir khudozhestvennogo proizvedeniya. Stilistika. Stikhovedeniye. Literaturnyy protsess [School dictionary of literary terms: the world of a work of art. Stylistics. Prosody. Literary process], ed. 4. Moscow, Prosveshcheniye Publ., 2013.

7. Yanovskaya L.M. O rasskaze Mikhaila Bulgakova «Khanskiy ogon» [About Mikhail Bulgakov's story “Khan's fire”]. In: Nash sovremennik [Our contemporary], 1974, no 2, pp. 124-126. 